\title{
PHYSIOLOGICAL EFFECTS OF HIGH TEMPERATURE TREATMENTS ON TOMATO LEAVES AT TWO DEVELOPMENTAL PHASES
}

\author{
Ece Turhan ${ }^{1, *}$, Cigdem Aydogan $^{1}$, Sergul Ergin ${ }^{1}$ \\ ${ }^{1}$ Eskisehir Osmangazi University, Faculty of Agriculture, Department of \\ Agricultural Biotechnology, 26160 Eskisehir, Turkey
}

\begin{abstract}
This study was conducted to investigate the effects of high temperatures on three tomato cultivars at first bloom and yield stages. The leaves were subjected to high temperature stress at 35, 40, 45, 50, 55 and $60^{\circ} \mathrm{C}$ with gradual increments every 30-minutes in both stages. Samples were analyzed for total chlorophyll (Chl), carotenoid (Car), ascorbic acid (AsA), glutathione (GSH), total soluble protein (TSP) contents. Besides, protein profiles were determined with SDS-PAGE. Heat stress decreased Chl content in both stages, while it was higher in first bloom stage than in yield stage. Whereas carotenoid content increased in both stages. The AsA and GSH contents were higher in yield stage than in first bloom stage. Heat stress, generally reduced AsA content, while increased GSH content. It was observed that the effect of cultivars and temperature treatments on the TSP content was different in both periods. In addition, TSP content had decreased with increasing temperatures, while many protein bands had been observed in SDS-PAGE with sizes ranging from $13 \mathrm{kDa}$ to $89 \mathrm{kDa}$ according to treatments.
\end{abstract}

Keywords: Chlorophyll, heat stress, non-enzymatic antioxidant, protein, Solanum lycopersicum.

\section{INTRODUCTION}

Changing environmental conditions, such as increasing temperature, is a major concern for crop production worldwide because it greatly affects the growth, development and productivity of plants. Plants exposed to excess heat exhibit a characteristic set of cellular and metabolic responses, many of which are conserved in all organisms (Fahad et al., 2017). The high temperature induced inactivation of photosynthesis has been related to membrane damage and changes of chlorophyll (Chl) and carotenoid (Car) contents (Camejo et al., 2005).

Heat stress induces the production of ROS (reactive oxygen species), which at elevated concentrations will result in oxidative damage (Apel and Hirt, 2004) and severely reduce the yield of tomato (Tonhati et al., 2020). As sessile organisms, plants developed remarkable capabilities to rapidly respond to multiple environmental changes from which they cannot escape (Boycheva et al., 2014). Under high temperature conditions, plants accumulate different metabolites such as nonenzymatic and enzymatic antioxidants, osmoprotectants, heat shock proteins besides, different metabolic pathways and processes are activated (Foyer and Noctor, 2005). In the non-enzymatic defense system, antioxidant compounds such as Car, ascorbic acid (AsA), glutathione (GSH), and 
$\alpha$-tocopherol play an important role in the removal of toxic oxygen compounds (Hodges et al., 1996).

Another hypothesis put forward about adaptation to high temperature is the presence of some adaptation mechanisms; involving protein promotion and differentiated protein function (Teeri, 1980). Because many of the stress proteins are water-soluble, they probably contribute to the stress tolerance of cellular structures through hydration (Wahid and Close, 2007).

Plant responses to high temperature also vary across and within species, as well as at different developmental stages. Tomato (Solanum lycopersicum) is an important vegetable crop all over the world. The optimum range of daytime temperatures for tomato seedlings growth, ranges from 18 to $30^{\circ} \mathrm{C}$, with an upper limit of $35^{\circ} \mathrm{C}$ (Abdalla et al., 2020). On the other hand, the optimum temperature during tomato plant flowering and fruit growth, ranges from 18 to $25^{\circ} \mathrm{C}$ (Tonhati et al., 2020). In addition, as a field and greenhouse-grown crop it is often subject to high temperatures during cultivation. Physiological observations both under field and greenhouse conditions show a variable degree of tolerance between different genotypes. Therefore early selection of plants tolerant to low or high temperatures using molecular or physiological tools can enhance the development of tolerant plants varieties. The aim of this research was to determine non-enzymatic antioxidant and protein reaction in response to heat stress in two different developmental stages (first bloom and yield stages) in three tomato cultivars.

\section{MATERIALS AND METHODS}

Leaves of tomato hybrid cvs. 'Çaltı', 'Pembe' and 'Yaren' were used in the study. The samples were obtained in June and August from plants grown in a field under favourable conditions for tomato production, in Eskisehir, Turkey (longitude: $39^{\circ} 45^{\prime} 38^{\prime \prime} \mathrm{N}$, latitude: $30^{\circ} 28^{\prime} 47^{\prime \prime} \mathrm{E}$ ) during first bloom and yield period. In June, the average temperature was $21.7^{\circ} \mathrm{C}$ (range $7.0^{\circ} \mathrm{C}-35.2^{\circ} \mathrm{C}$ ). In August, the average temperature was also $21.7^{\circ} \mathrm{C}$ (range $4.8^{\circ} \mathrm{C}-35.4^{\circ} \mathrm{C}$ ). The third leaf from the top of the plants were collected for heat stress treatments. High temperatures were generated artificially by gradually increasing the temperature according to Arora et al. (1998) with some modifications. Briefly, leaves obtained from plants during first bloom and yield period were collected into pyrex tubes with caps closed and placed into water bath. After a 30-min habituation of the sample containing tubes in water bath adjusted to $35^{\circ} \mathrm{C}$, the water temperature was inclined to $40^{\circ} \mathrm{C}$ in half an hour. Samples were then subjected to $40,45,50,55$ and $60^{\circ} \mathrm{C}$ temperatures with gradual increments every half an hour. Leaves collected from heat treated and control plants were analyzed for total Chl, Car, AsA, GSH contents and protein analyses.

Changes in total Chl content of tomato leaves were analyzed as described by Moran and Porath (1980). Leaf samples subjected to dimethylformamide (DMF) extraction were incubated at $4^{\circ} \mathrm{C}$ for 72 hours. The absorbance of supernatants was measured at $652 \mathrm{~nm}$ by a spectrophotometer (Perkin Elmer Lambda 25, USA). Data were expressed as $\mathrm{mg} \mathrm{g} \mathrm{FW}^{-1}$.

The total Car content was quantified spectrophotometrically according to Lichtenthaler and Wellburn (1983) with some modifications. Fresh leaf tissues were homogenized in ice with a homogenizer (Miccra D-1, Germany). Extracts were shaken at $120 \mathrm{rpm}$ for three hours in the dark. Fifteen minutes later, the absorbance of the extract at $460 \mathrm{~nm}$ was measured.

Ascorbic acid (AsA) was determined according to Law et al. (1983) with some modifications. The assay is based on the reduction of $\mathrm{Fe}^{3+}$ to $\mathrm{Fe}^{2+}$ by AsA in acidic solution. $\mathrm{Fe}^{2+}$ then forms complexes with bipyridyl, giving a pink colour that absorbs at $525 \mathrm{~nm}$. In extraction, $1 \mathrm{~g}$ of leaf samples were homogenized in $10 \mathrm{~mL}$ of $5 \%$ metaphosphoric acid and centrifuged at $22000 \mathrm{~g}$ for 15 
min. The reaction mixture for total AsA contained $0.2 \mathrm{~mL}$ aliquot of the supernatant, $0.5 \mathrm{~mL}$ of 150 $\mathrm{mM}$ sodium phosphate buffer ( $\mathrm{pH} 7.4$ ) containing $5 \mathrm{mM}$ ethylenediamine-tetraacetic acid (EDTA), $0.1 \mathrm{~mL}$ of $10 \mathrm{mM}$ dithiothreitol (DTT). After incubation for $15 \mathrm{~min}$ at room temperature, $0.1 \mathrm{~mL}$ $0.5 \%$ N-ethylmaleimide was added to remove excess DTT. For the occurrence of color formation due to the amount of AsA, $0.4 \mathrm{~mL}$ of $10 \%$ trichloroacetic acid (TCA), $0.4 \mathrm{~mL}$ of $44 \%$ orthophosphoric acid, $0.4 \mathrm{~mL}$ of $4 \% 2,2^{\prime}$-bipyridyl in $70 \%$ ethyl alcohol, and $0.2 \mathrm{~mL}$ of $3 \% \mathrm{FeCl}_{3}$ were added to reaction medium, respectively. The mixtures were then incubated for $40 \mathrm{~min}$ at $40^{\circ} \mathrm{C}$ and the absorbance was read in the mixtures at $525 \mathrm{~nm}$ using the spectrophotometer. Ranges of 0-100 $\mu \mathrm{g} \mathrm{mL}^{-1} \mathrm{~L}(+)$ ascorbic acid standards were used for the calculations and expressed as $\mathrm{mg} \mathrm{g} \mathrm{FW}^{-1}$. Glutathione (GSH) content was determined spectrophotometrically according to Ellman (1959) with some modifications. For this purpose $0.5 \mathrm{~g}$ of leaf sample was homogenized in $5 \mathrm{~mL}$ of $5 \%$ metaphosphoric acid and was centrifuged at $4000 \mathrm{~g}$ for $30 \mathrm{~min}$. Then, $2.5 \mathrm{~mL}$ of $150 \mathrm{mM}$ sodium phosphate $\left(\mathrm{Na}^{-} \mathrm{PO}_{4}\right)$ buffer ( $\mathrm{pH} 7.4$ ) containing $5 \mathrm{mM}$ EDTA and $0.5 \mathrm{~mL}$ of $6 \mathrm{mM} \mathrm{5,5'-dithiobis-2-}$ nitrobenzoic acid (DTNB) was added to the supernatant. After the samples were incubated at room temperature for $20 \mathrm{~min}$, the absorbance was read at $412 \mathrm{~nm}$. Reduced glutathione standards were used for the calculations and the GSH was expressed as $\mu \mathrm{g} \mathrm{FW}^{-1}$.

Total soluble protein was extracted from leaf tissues using the extraction methods described by Arora et al. (1992), with few modifications. Ground leaf tissues $(1 \mathrm{~g})$ were homogenized at $4{ }^{\circ} \mathrm{C}$ in borate buffer $[50 \mathrm{mM}$ sodium tetraborate, $50 \mathrm{mM}$ AsA, $1 \%$ b-mercaptoethanol, $1 \mathrm{mM}$ phenylmethylsulfonyl fluoride (PMSF), $\mathrm{pH}$ 9.0] and insoluble polyvinylpolypyrolidone (PVPP) paste made with borate buffer using a 1:5:2 (tissue: buffer: PVPP paste) extraction ratio. Samples were shaken on a gyratory shaker for $15 \mathrm{~min}$ at $4^{\circ} \mathrm{C}$ followed by centrifugation at $26000 \mathrm{~g}$ for 1.5 $\mathrm{h}$ at $4^{\circ} \mathrm{C}$. The resulting supernatant was collected and filtered through cheesecloth. Protein content was measured using the Bradford assay method (Bradford, 1976).

Proteins were precipitated according to the method described by Lim et al. (1999), by adding TCA to $1 \mathrm{~mL}$ of sample from the supernatant. Samples were centrifuged at $16000 \mathrm{~g}$ for $30 \mathrm{~min}$ at $4{ }^{\circ} \mathrm{C}$, after $30 \mathrm{~min}$ incubation at $4^{\circ} \mathrm{C}$. Protein pellets were washed three times with cold acetone and centrifuged at $16000 \mathrm{~g}$ for $30 \mathrm{~min}$ at $4^{\circ} \mathrm{C}$. After the first acetone wash, pellets were broken physically using a sealed pipette tip. Dried pellets were resuspended in SDS-PAGE sample buffer (65 mM Tris-HCl, $100 \mathrm{~mL} \mathrm{~mL}^{-1}$ (v/v) glycerol, $20 \mathrm{mg} \mathrm{mL}^{-1}$ (w/v) SDS, $\mathrm{pH} 6.8$ and $50 \mathrm{~mL} \mathrm{~mL}^{-1} \mathrm{~b}-$ mercaptoethanol with Bromphenol Blue). Discontinuous SDS-PAGE was performed with a PROTEAN tetra vertical electrophoresis unit (Bio-Rad, Hercules, CA, USA) using 0.04 stacking gel and 0.125 separating gel. An equal amount of total protein $(30 \mu \mathrm{g})$ was loaded for each sample and gels were stained with Coomassie Brilliant Blue G-250.

The experiment was arranged in a randomized block design, with three replications. The data were tested with SPSS 22.0 for Windows (SPSS Inc., Chicago, IL, USA) and mean separation was accomplished by the Duncan test at $\mathrm{P}<0.05$.

\section{RESULTS AND DISCUSSIONS}

Effects of heat treatments on Chl content of the leaves of three tomato cultivars are summarized in Figure 1A. When compared to control treatment, heat treatments caused a decrease in Chl content in all cultivars. The Chl content decreased gradually from control to the highest temperature $\left(60^{\circ} \mathrm{C}\right)$. Total $\mathrm{Chl}$ content in the first bloom period was significantly higher than that in the yield period. The Chl content decreased gradually from $\sim 6.0 \mathrm{mg} \mathrm{g} \mathrm{FW}^{-1}$ (in the control) to $4.9 \mathrm{mg} \mathrm{g} \mathrm{FW}^{-1}$ (at $50^{\circ} \mathrm{C}$ ) in cv. 'Çaltı'. On the other hand, cv. 'Pembe' had the lowest leaf Chl content with approximately 


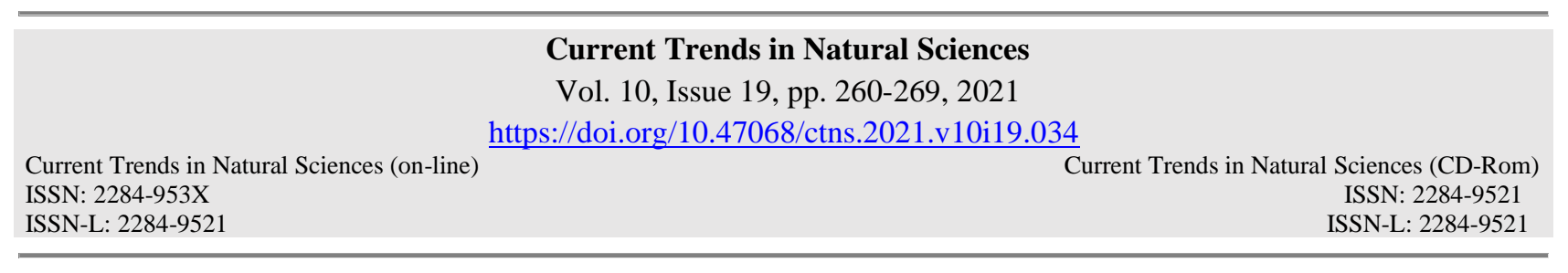

$3.5 \mathrm{mg} \mathrm{g} \mathrm{FW}^{-1}$. The highest relative decrease in Chl content was found in cv. 'Yaren' (45.8 \%). At the same time, ANOVA result indicated that a significant effect of sampling period, heat stress treatments and cultivar with regard to total $\mathrm{Chl}$ content. Moreover, interaction between the cultivar and heat treatments was also significant (Table 1).

Data obtained from the current research revealed that total Car content of leaf tissues increased gradually from control to the highest temperature $\left(60^{\circ} \mathrm{C}\right)$ in both sampling stages in three cultivars (Average; Control: $0.16 \mathrm{mg} \mathrm{g} \mathrm{FW}^{-1}, 60^{\circ} \mathrm{C}: 0.26 \mathrm{mg} \mathrm{g} \mathrm{FW}^{-1}$, Figure 1B). The statistical analysis found a significant effect of heat treatments, but no significant effect of sampling period, cultivars and their interactions (Table 1).

Parallel to this research, Bhattaraie et al. (2021) reported that the Chl content of tomato decreased with temperature and duration of heat stress, suggesting damage of the photosynthetic reaction centers (Bowler et al., 1992). High temperature stress disrupts the growth and development of olive tree by inhibiting photosynthesis particularly when the temperature is above $50^{\circ} \mathrm{C}$ in olive plant (Cansev, 2012). Bhattarai et al.(2021) also found that heat-tolerant tomato genotypes, selected by using Chl fluorescence exhibited heat tolerance in open-field environments. The ROS induced in the chloroplast under abiotic stresses can oxidize carotenoids (Havaux, 2014). Carotenoid is a lipidsoluble antioxidant that plays multiple roles in plant metabolism, including oxidative stress tolerance (Gill and Tuteja, 2010). High light and heat stress caused significant reduction Chl content as well as increase in Car in tomato plants (Zhou et al., 2020). In addition Zhou et al. (2020) pointed out that the tomato plants developed their defense systems including Chl loss and synthesis of Car to protect themselves from multiple stresses.
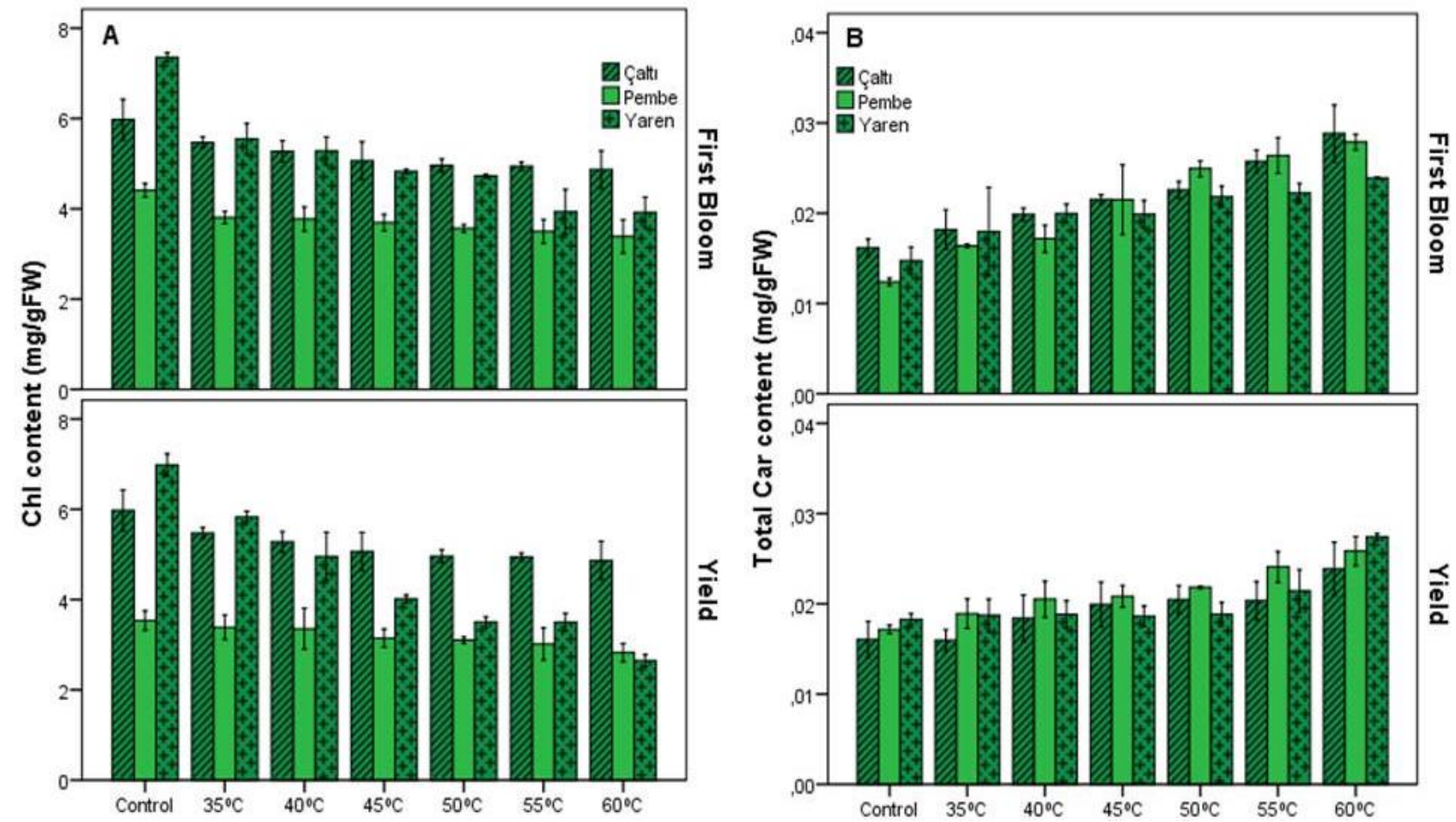

Figure 1. Effect of heat treatments on the leaf chlorophyll (Chl) (Panel A) and carotenoid (Car) (Panel B)contents of tomato cultivars in first bloom and yield stage. Vertical lines on bars indicate \pm standard errors (SE) of repetitions 
Total AsA content of in the leaf of three tomato cultivars in both sampling stages is shown in Figure 2A. Heat stress treatments generally reduced the total AsA content according to control treatment in the seedling stage. However, total AsA content in three tomato cultivars was significantly higher in yield stage $\left(\sim 1.2 \mathrm{mg} \mathrm{gFW}^{-1}\right)$ than in first bloom stage $\left(\sim 0.6 \mathrm{mg} \mathrm{gFW}^{-1}\right)$. Total AsA content was generally higher in cv. 'Yaren' than in cvs. 'Pembe' and 'Çaltı'. According to the statistical analysis, it was found a significant effect of heat treatments, sampling period, cultivars and their interactions on total AsA content (Table 1).

Glutathione content values of the leaf samples fluctuated depending on temperature applications. In general, the mean GSH content in the first bloom stage $\left(\sim 936 \mu \mathrm{g} \mathrm{FW}^{-1}\right)$ was significantly lower than that in the yield stage $\left(1076 \mu \mathrm{g} \mathrm{g} \mathrm{FW}^{-1}\right)$. Current research revealed that cv. 'Pembe' had higher GSH content than cvs. 'Yaren' and 'Çaltı' in all sampling stages (Figure 2B). The effect of sampling stage along with cultivar and heat stress treatment and their interaction on GSH content was statistically significant (Table 1 ).

Ascorbic acid, one of the non-enzymatic antioxidants, is a scavenger of many ROS due to its ability to donate electrons. Glutathione reacts with free radicals formed in a stress condition, preventing the sulfhydryl $(\mathrm{SH})$ groups of enzymes from oxidizing. These antioxidants play a role in eliminating the damage that stress can cause (Foyer, 1993; Lamb and Dixon, 1997). Oxidative protection is an important component for determining the viability of a plant during heat stress. The present study revealed that, high temperature treatments generally reduced the total AsA content in all cultivars in the first bloom stage. However, in the yield period, although the total amount of AsA changed depending on the temperature applications, it did not show any increase or decrease trend. This may be due to the accumulation of ROS in the cell and the activation of other defense mechanisms in the removal of these ROS from the environment. Similarly, the increase in the amount of GSH because of high temperature applications may be due to an increase in the level of ROS in the environment and the cell increases the production of GSH from protective antioxidants in response to this. Researches in peas and corn have also shown that high temperature applications increase the GSH content (Nieto-Sotelo and Hu, 1986). It was determined that the contents of AsA and GSH in heatacclimated leaves were higher than those in control at same heat stress level though the contents of AsA and GSH showed the trend of significant decrease with increase in heat stress levels. (Xu et al., 2006). In lilium, Yin et al. (2008) noted that AsA and GSH concentrations were at high levels after 10 hours of application at 37 and $42^{\circ} \mathrm{C}$. However, they determined that after 10 hours of application at $47{ }^{\circ} \mathrm{C}$, the GSH concentration was the same as the control, and the AsA concentration decreased compared to the control due to the increase in $\mathrm{O}_{2}{ }^{-}$and $\mathrm{H}_{2} \mathrm{O}_{2}$. (Yin et al., 2008). Ergin et al. (2016) reported that the contents of AsA and GSH did not change depending on heat stress type, temperatures, or cultivars in strawberry plants.

All the three cultivars had a significantly higher TSP content in the leaf tissues in the first bloom stage than in the yield stage (Figure 3). The data from the two sampling stages showed that the TSP content of cv. 'Yaren' ( $9.8 \mathrm{mg} \mathrm{g} \mathrm{FW}^{-1}$; Figure 3$)$ was greater than that of cvs. 'Çaltı' $\left(8.9 \mathrm{mg} \mathrm{g} \mathrm{FW}^{-1}\right.$; Figure 3) and 'Pembe' (8.6 $\mathrm{mg} \mathrm{g} \mathrm{FW}^{-1}$; Figure 3). Statistical analysis found a significant effect of sampling stage, cultivar, heat treatments and interaction between sampling stage, cultivar and heat treatments on TSP content (Table 1). 


\section{Current Trends in Natural Sciences}

Vol. 10, Issue 19, pp. 260-269, 2021

https://doi.org/10.47068/ctns.2021.v10i19.034

Current Trends in Natural Sciences (on-line)
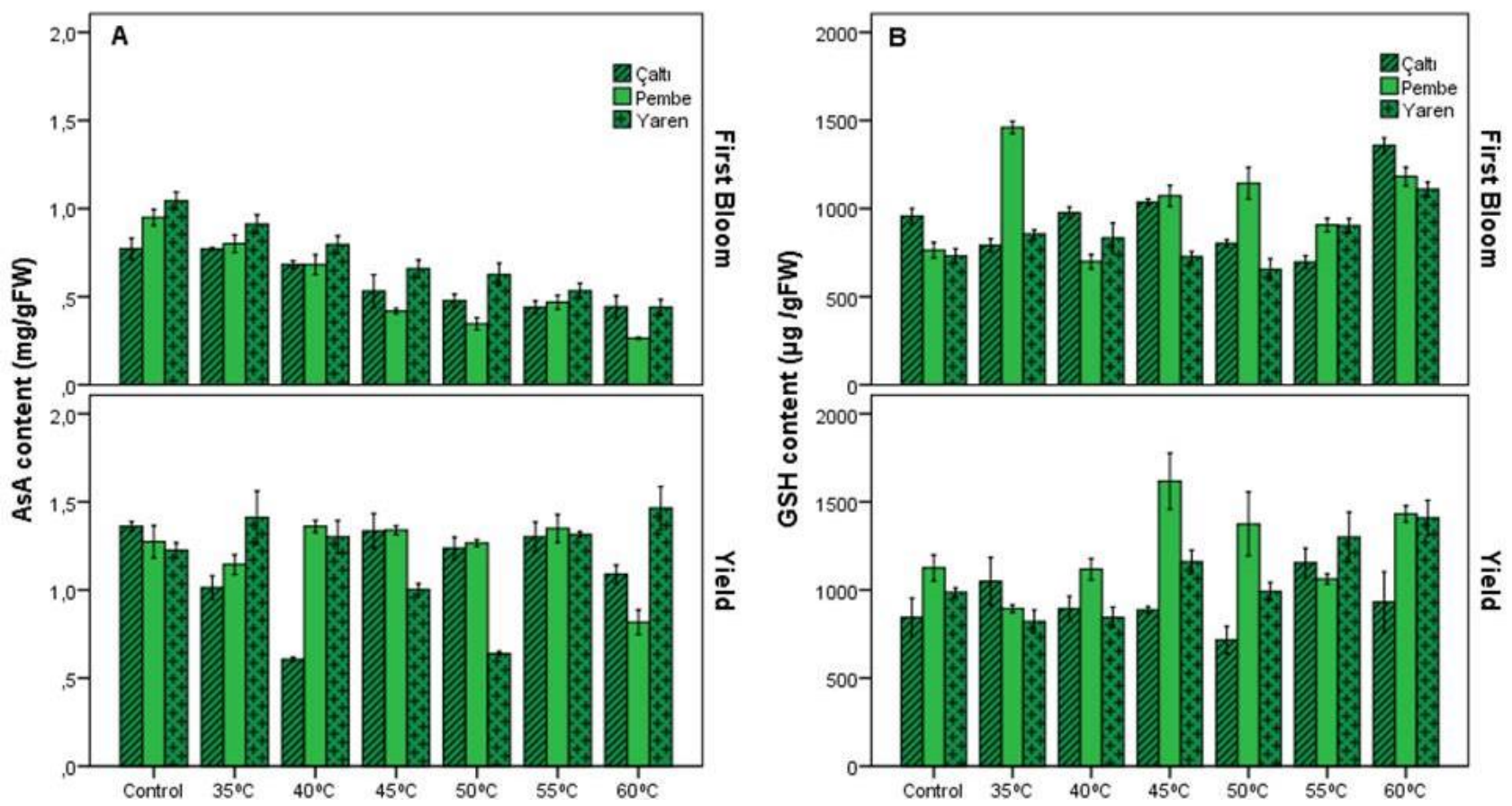

Figure 2. Effect of heat treatments on the leaf ascorbic acid (AsA) (Panel A) and gltathione (GSH) (Panel B) contents of tomato cultivars in first bloom and yield stage. Vertical lines on bars indicate \pm standard errors (SE) of repetitions

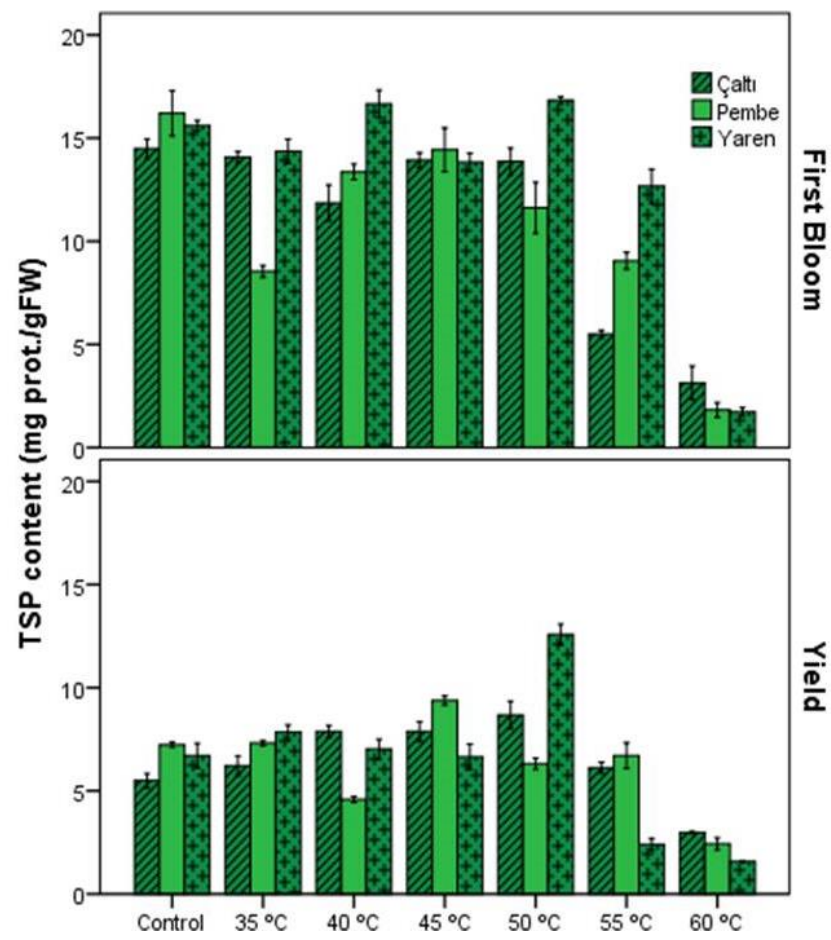

Figure 3. Effect of heat treatments on the total soluple protein (TSP) content of tomato cultivars in first bloom and yield stage. Vertical lines on bars indicate \pm standard errors (SE) of repetitions 


\section{Current Trends in Natural Sciences}

Vol. 10, Issue 19, pp. 260-269, 2021

Current Trends in Natural Sciences (on-line)

https://doi.org/10.47068/ctns.2021.v10i19.034

Current Trends in

Current Trends in Natural Sciences (CD-Rom)

ISSN: 2284-9521

ISSN-L: 2284-9521

ISSN-L: 2284-9521

Table 1. Results of analysis of variance (ANOVA) of period (P), cultivar (Cv.) temperature (T) and their interactions with Chl, karotenoid, AsA, GSH and TSP content in leaf tissues. Numbers represent $F$ values relative to a significance level of 0.05

\begin{tabular}{|c|c|c|c|c|c|c|c|}
\hline \multirow{2}{*}{$\begin{array}{l}\text { Dependent } \\
\text { Variable }\end{array}$} & \multicolumn{7}{|c|}{ Independent Variable } \\
\hline & $\mathrm{P}$ & $\mathrm{Cv}$. & $\mathrm{T}$ & $\mathrm{P} \times \mathrm{Cv}$ & $\mathrm{P} \times \mathrm{T}$ & $\mathrm{Cv} . \times \mathrm{T}$ & $\mathrm{P} \times \mathrm{Cv} . \times \mathrm{T}$ \\
\hline Chl & $19.921 *$ & $158.526^{*}$ & $35.196^{*}$ & $5.059 *$ & $0.756^{\mathrm{ns}}$ & $8.614^{*}$ & $0.699^{\mathrm{ns}}$ \\
\hline Car & $1.407^{\mathrm{ns}}$ & $0.952^{\mathrm{ns}}$ & $23.880^{*}$ & $2.984^{\mathrm{ns}}$ & $1.822^{\mathrm{ns}}$ & $0.676^{\mathrm{ns}}$ & $0.652^{\mathrm{ns}}$ \\
\hline AsA & $755.496^{*}$ & $7.469 *$ & $21.143^{*}$ & $6.674^{*}$ & $13.921 *$ & $7.807 * *$ & $9.420 *$ \\
\hline GSH & $31.247^{*}$ & $25.931 *$ & $13.053 *$ & $10.144 *$ & $4.991 *$ & $4.804^{*}$ & $6.837^{*}$ \\
\hline TSP & $1046.712 *$ & $23.234 *$ & $226.405 *$ & $21.754 *$ & $42.798 *$ & $16.077 *$ & $13.655^{*}$ \\
\hline
\end{tabular}

*, ns Significant and not significant at $\mathrm{p}<0.05$, respectively.

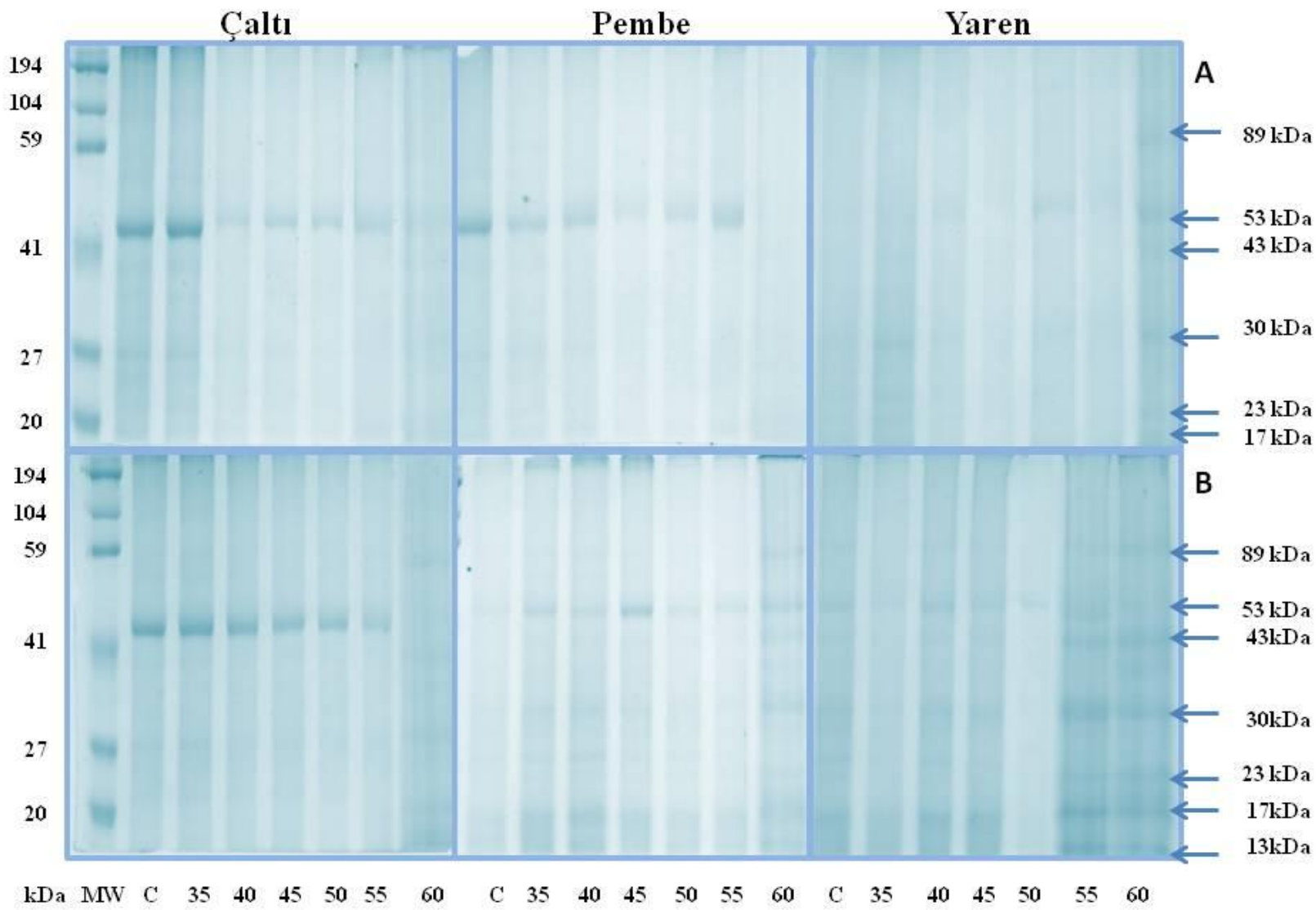

Temperature $\left({ }^{\circ} \mathrm{C}\right)$

Figure 4. Effect of heat treatments on the SDS-PAGE protein profiles of tomato cultivars in first bloom (PanelA) and yield stage(Panel B). In each lane, $30 \mu \mathrm{g}$ of protein was loaded. Molecular weight markers (MW) and the molecular mass (kDa) are shown on the left-hand side 
Figure 4 shows the total protein profiles of tomato cultivars in both sampling stages depending on high temperature applications. According to the SDS-PAGE profiles, at first bloom stage, four protein bands estimated as 17, 30, 43 and $53 \mathrm{kDa}$ were noted in cv. 'Çaltı'. Besides, 17, 30 and 53 $\mathrm{kDa}$ size of the bands have been observed in cv. 'Pembe' along with 17, 23, 30, 43, 53 and $89 \mathrm{kDa}$ size of bands have been observed in $\mathrm{cv}$. 'Yaren'. The $43 \mathrm{kDa}$ protein band was observed from the control to $60^{\circ} \mathrm{C}$ in $\mathrm{cv}$. 'Çalt1'. The $30 \mathrm{kDa}$ protein band disappeared after $35^{\circ} \mathrm{C}$ treatment in $\mathrm{cv}$. 'Pembe'. On the other hand, the $43 \mathrm{kDa}$ protein band was detected only at $60^{\circ} \mathrm{C}$ treatment at first bloom stage. According to SDS-PAGE profiles at yield stage, it is thought that the protein bands with the the size of 30 and $53 \mathrm{kDA}$ probably structural proteins while the size of $89 \mathrm{kDa}$ protein band occur with temperature applications in tomato plants. The sizes of 13 and $17 \mathrm{kDa}$ protein bands in cvs. 'Pembe' and 'Yaren', but the same band was not detected in cv. 'Çaltı' cultivar. Different from the other cultivars a protein band of $43 \mathrm{kDa}$ was found in cv. 'Yaren' at yield stage (Figure 4).

The early changes caused by high-temperature stress involve in the reprogramming of signal transduction components, transcription factors and proteins associated with the metabolism of ROS under stressful conditions (Dou et al., 2015). Tokyol and Turhan (2019) reported that in 'Balk1z', 'Ferasetsiz' and 'Local Genotype' green bean genotypes, the TSP content reduced and/or increased depending on the temperature and genotypes. Similarly, Turhan et al. (2015) reported that heat stress application increased the TSP content up to certain temperatures in pepper cultivars. Ergin et al. (2016) also determined that TSP content decreased, while new proteins had been synthesized depending on increased temperatures in strawberry cultivars. It was declerated that new proteins are synthesized or reduced and almost complete lost in tomatoes in response to high temperature (Heckathorn et al., 1998). In addition, Turhan et al. (2015) found that strips of 7-54 kDa in the pepper plant under high temperature stress conditions and $40 \mathrm{kDa}$ protein band may be associated with high temperature tolerance. The preservation of protein structures and functions under stress conditions is very important for the survival of the cell (Wang et al., 2004).

\section{CONCLUSIONS}

In conclusion, high temperature stress disrupts the growth and development of tomato by inhibiting photosynthesis. It has been determined that the high temperature tolerance level changes depending on the growth period of the tomato plants, there is no significant difference between the cultivars used in the study. Besides, it was found that in terms of tolerance to high temperature, nonenzymatic antioxidants AsA and GSH are effective in high temperature tolerance of tomato plants. In addition, it was also determined that TSP content decreased in parallel with the increase in temperature, whereas the synthesis of some proteins increased. Further researches on molecular basis are needed to clarify the heat stress tolerance of tomato plants.

\section{ACKNOWLEDGEMENTS}

Grants from the Scientific Research Projects Commission of Eskisehir Osmangazi University (Project No: 201323006) supported the current research.

\section{REFERENCES}

Abdalla, N. Taha, N., El-Ramady, H., Bayouml, Y. (2020). Management of Heat Stress in Tomato Seedlings under Arid and Semi-Arid Regions: A Review. Env. Biodiv. Soil Security 4, 47-59.

Apel, K. Hirt, H. (2004). Reactive oxygen species: metabolism, oxidative stress, and signal transduction. Annu. Rev. Plant Biology, 55, 373-399. 
Arora, R., Pitchay, D.S., Bearce, B.C. (1998). Water stress-induced heat tolerance in geranium leaf tissues: A possible linkage through stress proteins, Physiologica Plantarum, 103, 24-34.

Arora, R., Wisniewski, M.E., Scorza, R. (1992). Cold acclimation in genetically related (sibling) deciduous and evergreen peach (Prunus persica L. Batsch). I. Seasonal changes in cold hardiness and polypeptides of bark and xylem tissues. Plant Physiol, 99, 1562-1568.

Bhattarai, S., Harvey, J.T., Djidonou, D., Leskovar, D.I. (2021). Exploring morpho-physiological variation for heat stress tolerance in tomato. Plants, 10, 347.

Bowler, C., M. Van Montagu and D. Inze (1992). Superoxide dismutase and stress tolerance. Annu. Rev. Plant Physiol.Plant Mol. Biol., 43, 83-116.

Boycheva, I., Vassileva, V., Lantcheva, A. (2014). Histone acetyltransferases in plant development and plasticity. Current Genomics 15(1), 28-37.

Bradford, M.M. (1976). A rapid and sensitive method for the quantitation of microgram quantities of protein utilizing the principle of protein-dye binding. Analytical Biochemistry, 72(1-2), 248-254.

Camejo, D., Rodriguez, P., Morales, M.A., Dell'amico, J.M., Torrecillas, A., Alarcon, J.J. (2005). High temperature effects on photosynthetic activity of two tomato cultivars with different heat susceptibility. J. Plant Physiol. 162, 281-289.

Cansev, A. (2012). Physiological effects of high temperature treatments on leaves of olive cv. 'Gemlik'. Plant Arch 12, $521-525$

Dou, H., Xv, K., Meng, Q., Li, G., Yang, X. (2015). Potato plants ectopically expressing Arabidopsis thaliana CBF3 exhibit enhanced tolerance to high-temperature stress. Plant Cell Environ.,38(1), 61-72.

Elman, G.L. (1959). Tissue suphydriyl groups. Arch. Biochem. Biophys., 82, 70-77.

Ergin, S., Gülen, H., Kesici, M., Turhan, E., Ipek, A., Köksal, N. (2016). Effects of high temperature stress on enzymatic and nonenzymatic antioxidants and proteins in strawberry plants. Turkish Journal of Agriculture and Forestry, 40(6), 908-917.

Fahad, S., Bajwa, A.A., Nazir, U., Anjum, S.A., Farooq, A., Zohaib, A., Sadia, S., Nasim, W., Adkins, S., Saud, S. and Ihsan M.Z. (2017) Crop production under drought and heat stress: plant responses and management options. Frontiers in Plant Science, 8, 1147.

Foyer, C.H. (1993). Ascorbic acid: Antioxidants in higher plants, Eds: Alscher, R.G., Hess, J.L., CRC Pres, Boca Raton, 31-58.

Foyer, C.H., Noctor, G. (2005), Oxidant and antioxidant signalling in plants: a re-evaluation of the concept of oxidative stress in a physiological context. Plant, Cell \& Environment, 28: 1056-1071.

Gill, S.S. Tuteja, N. (2010). Reactive oxygen species and antioxidant machinery in abiotic stress tolerance in crop plants. Plant Physiol Biochem, 48, 909-930.

Havaux, M. (2014). Carotenoid oxidation products as stress signals in plants. Plant J., 79, 597-606.

Hodges, D.M., Andrews, C.J., Johnson, D.A., Hamilton, R.I. (1996). Antioxidant compound responses to chilling stress in differentially sensitive inbred maize lines. Physiol. Plant. 98, 685-692.

Lamb C, Dixon RA. (1997). The oxidative burst in plant disease resistance. Annu Rev Plant Physiol Plant Mol Biol., 48, 251-275.

Law, M.Y., Charles, S.A., Halliwell, B. (1983). Glutathione and ascorbic acid in spinach (Spinacia oleracea) chloroplasts: The effect of hydrogen peroxide and of paraquat. Biochem J., 210 (3), 899-903.

Lichtenthaler, H.K., Wellburn, A.R. (1983). Determinations of total carotenoids and chlorophylls a and b of leaf extracts in different solvents. Biochem Soc Trans 11, 591-592.

Lim, C.C., Krebs, S.L., Arora, R.A. (1999). 25-kDa dehydrin associated with genotypeand age-dependent leaf freezingtolerance in Rhododendron: a genetic marker for cold hardiness? Theor. Appl. Genet. 99, 912-920.

Moran, R., Porath, D. (1980). Chlorophyll determination in intact tissues using N,N dimethylformami.de. Plant Physiology, 65, 478-479.

Nieto-Sotelo, J., Ho, T.H.D. (1986). Effect of heat shock on the metabolism of glutathione in maize roots. Plant Phisiology, 82, 1031-1035.

Teeri, J.A. (1980). Adaptation of kinetic properties of enzymes to temperatures variability, in:N.C. Turner, P.J. Kramer (Eds.), Adaptation of plants to water and high temperature stres, Willey-Interscience, New York, pp: 251-260.

Tokyol, A., Turhan, E. (2019). Heat stress tolerance of some green bean (Phaseolus vulgaris L.) genotypes. Scientific Papers. Series A. Agronomy, LXII, (1), 472-479.

Tonhati, R., Mello, S. C., Momesso, P. and R. M. Pedroso (2020) L-proline alleviates heat stress of tomato plants grown under protected environment. Scientia Horticulturae, 268, 109370. 


\section{Current Trends in Natural Sciences}

Vol. 10, Issue 19, pp. 260-269, 2021

https://doi.org/10.47068/ctns.2021.v10i19.034

Current Trends in Natural Sciences (on-line)

ISSN: 2284-953X

Current Trends in Natural Sciences (CD-Rom)

ISSN-L: 2284-9521

Turhan, E., Aydogan, C., Ergin, S., Ozturk, N. (2015). Proteins in pepper plants (Capsicum annuum L.) under heat stress. Journal of Biotechnology, 208, 31.

Xu, S., Li, J., Zhang, X., Wei, H., Cui, L. (2006). Effects of heat acclimation pretreatment on changes of membrane lipid peroxidation, antioxidant metabolites, and ultrastructure of chloroplasts in two cool-season turfgrass speciaes under heat stress. Environ. Exper. Botany, 56, 274-285.

Wahid, A., Close, T.J. (2007). Expression of dehydrins under heat stress and their relationship with water relations of sugarcane leaves. Biol. Plant., 51, 104-109.

Wang, W., Vinocur, B., Shoseyov, O., Altman, A. (2004). Role of plant heat-shock proteins and molecular chaperones in abiotic stress response. Trends in Plant Sci., 9(5): 244-253.

Yin, H., Chen, Q., Yi, M. (2008). Effects of short-term heat stress on oxidative damage and responses of antioksidant system in Lilium longiflorum. Plant Growth Regul., 54, 45-54.

Zhou, R., Yu, X., Li, X., dos Santos, T.M., Rosenqvist, E., Ottosen, C-O. (2020). Combined high light and heat stress induced complex response in tomato with better leaf cooling after heat priming. Plant Physiology and Biochemistry, 151, 1-9. 